\title{
Effect of dietary levels of lipid and carbohydrate on growth performance, body composition, nitrogen excretion and plasma glucose levels in rainbow trout reared at 8 or $18^{\circ} \mathrm{C}$
}

\author{
C Brauge, G Corraze, F Médale \\ Laboratoire de nutrition des poissons, unité mixte INRA-IFREMER, station d'hydrobiologie INRA, \\ 64310 Saint-Pée-sur-Nivelle, France
}

(Received 9 September 1994; accepted 10 February 1995)

\begin{abstract}
Summary - Trout reared at 8 or $18^{\circ} \mathrm{C}$ were fed twice a day almost to satiation with 1 of 3 experimental diets. The diets were formulated to contain the same levels of protein ( $43 \%$, dry matter (DM) basis) and digestible energy (around $15 \mathrm{~kJ} / \mathrm{g} \mathrm{DM}$ ), but different carbohydrate/ipid ratios (30:7 to 23:14). Time-course studies of nitrogen excretion and glycaemia were also carried out. After 12 weeks of feeding, growth, protein retention and body composition were not influenced by the dietary treatment in trout reared at $8^{\circ} \mathrm{C}$. At $18^{\circ} \mathrm{C}$, the protein retention was not affected by dietary treatment, but the weight gain tended to be higher in trout fed the diet with the lowest carbohydrate/lipid ratio. This result was due to higher body lipid deposition in these trout. Nitrogen excretion was not influenced by dietary treatment, but was higher at $18^{\circ} \mathrm{C}$ than at $8^{\circ} \mathrm{C}$ because of a higher feed intake. Glycaemia increased with dietary level of digestible carbohydrate and the highest plasma glucose level was attained later at $8^{\circ} \mathrm{C}$ in comparison to $18^{\circ} \mathrm{C}$.
\end{abstract}

trout / carbohydrate/lipid ratio / growth performance / glycaemia / temperature

Résumé - Effets du rapport glucides/lipides de l'aliment sur les performances de croissance, la composition corporelle, l'excrétion azotée et le glucose plasmatique chez la truite Arc-en-ciel élevée à 8 ou $18^{\circ} \mathrm{C}$. Des truites Arc-en-ciel élevées à 8 ou $18^{\circ} \mathrm{C}$ ont été nourries 2 fois par jour à presque satiété avec l'un des 3 régimes expérimentaux. Les régimes ont été formulés pour contenir les mêmes taux de protéines (43\%, sur la base de la matière sèche (MS)) et d'énergie digestible (environ $15 \mathrm{~kJ} / \mathrm{g}$ MS), mais différents rapports glucides/ipides (30/7 à 23/14). Les évolutions dans le temps de l'excrétion azotée et de la glycémie ont aussi été étudiées. Après 12 sem d'alimentation, la croissance, la rétention protéique et la composition corporelle n'ont pas été influencées par le régime alimentaire chez les truites élevées à $8^{\circ} \mathrm{C}$. $\dot{A} 18^{\circ} \mathrm{C}$, la rétention protéique n'a pas été affectée par le régime alimentaire, mais le gain de poids tendait à être plus élevé chez les truites recevant le régime riche en lipides ( $16 \%$ MS). Ce résultat a été dû à un dépôt plus élevé en lipides chez ces truites. L'excrétion azotée n'a pas été influencée par le régime alimentaire, mais a été plus élevée à $18^{\circ} \mathrm{C}$ qu'à $8^{\circ} \mathrm{C}$ 
à cause d'une consommation d'aliment plus importante. Le taux de glucose plasmatique a augmenté avec la quantité de glucides digestibles du régime et le pic de glycémie est apparu plus tard à $8^{\circ} \mathrm{C}$ qu'à $18^{\circ} \mathrm{C}$.

truite / rapport glucides/lipides / performance de croissance / glycémie / température

\section{INTRODUCTION}

The high protein requirement for the growth of carnivorous fish gives rise to high food costs and elevated discharges of nitrogenous wastes into the environment.

The protein-sparing effect of lipid in fish is well established (Lee and Putnam, 1973; Reinitz et al, 1978; Takeuchi et al, 1978; De Silva et al, 1991). However, commercial diets containing high levels of lipids have only recently become available, owing to technological advances in fish feed manufacture.

Carbohydrates are a cheaper source of energy than either protein or lipid. Complex carbohydrates, such as crude starch, are poorly digested by fish (Singh and Nose, 1967; Bergot and Brèque, 1983). However, technological treatments of cereals or starch, such as gelatinization or extrusion, have been found to improve the digestibility of starch by cultured fish (Bergot and Brèque, 1983; Takeuchi et al, 1990; Jeong et al, 1991). Although the protein-sparing effect of the different sources and levels of carbohydrate has been debated (Hilton et al, 1987; Higgs et al, 1992), evidence suggests that dietary levels of digestible starch improve protein utilization efficiency in rainbow trout held at temperatures between 15 and $18^{\circ} \mathrm{C}$ (Pieper and Pfeffer, 1980; Kaushik and Oliva-Teles, 1985; Kaushik et al, 1989; Kim and Kaushik, 1992). Water temperature influences the utilization of dietary carbohydrate and lipid by rainbow trout; the digestibility of starch has been reported to be low in rainbow trout reared at $8^{\circ} \mathrm{C}$ relative to those held at $18^{\circ} \mathrm{C}$, and utilization of dietary lipid for energy production is depressed by dietary gelatinized starch more strongly at $18^{\circ} \mathrm{C}$ than at $8^{\circ} \mathrm{C}$ (Médale et al, 1991). Dixon and Hilton (1985) also found that high dietary carbohydrate levels had an adverse effect on liver function. This effect was more pronounced at low temperature. Growth of trout held at $6.5^{\circ} \mathrm{C}$ was also shown to be depressed when dietary glucose level reaches $15 \%$ of the diet (Higgs et al, 1992). The aim of this study was to assess the effect of dietary carbohydrate/lipid ratio on nutrient and energy utilization and its consequence on body composition in rainbow trout grown at high $\left(18^{\circ} \mathrm{C}\right)$ or low $\left(8^{\circ} \mathrm{C}\right)$ temperatures. The effect of dietary carbohydrate level and water temperature on nitrogen excretion and on the time-course of plasma glucose levels was also examined.

\section{MATERIALS AND METHODS}

\section{Experimental diets}

Three experimental pelleted diets were formulated to contain the same amounts of crude protein (43-44\% dry matter (DM)) but different carbohydrate/lipid ratios. The levels of lipid and carbohydrate and the type of carbohydrate (gelatinized or crude starch) were chosen to obtain diets providing the same amounts of digestible energy $(15,5 \mathrm{~kJ} / \mathrm{g} \mathrm{DM})$. Diet $\mathrm{HC}$ contained mainly gelatinized starch as the carbohydrate source and had a low lipid level. Diet MC contained a nearly equal mixture of gelatinized starch and crude starch, and an intermediate level of lipid. Diet LC contained mainly crude starch as the carbohydrate source, and had a high lipid level (table I). Theoretical digestible energy contents of the diets were calculated by addition of the values for individual dietary ingredients. The digestible energy of each ingredient was estimated using 
Table I. Ingredients and proximate composition of the experimental diets.

$\begin{array}{lll}\text { Ingredients (\%) Diet HC Diet MC D L } & \text { Diet }\end{array}$

Fish meal a

Fish oil b

Gelatinized wheat starch

Crude wheat starch

Vitamin mix ${ }^{c}$

Mineral mix d

Sodium alginate

\section{Proximate composition}

Crude protein (\% DM)

Crude lipid (\% DM)

Starch (\% DM)

Ash (\% DM)

Gross energy ( $\mathrm{kJ} / \mathrm{g} \mathrm{DM})$
60.1

0.0

30.1

6.8

1.0

1.0

1.0
60.1

4.9

16.6

15.4

1.0

1.0

1.0
60.1

9.8

0.6

26.5

1.0

1.0

1.0

a Norwegian herring fish meal (CP: $9.8 \% \mathrm{DM})$; ${ }^{\circ}$ acidity value: $6 \%$, stabilized with 200 ppm ethoxyquin, peroxide index < 10, iodine index between 140 and 160; c vitamin mix ( $\mathrm{mg} / \mathrm{kg}$ diet): vitamin A acetate, 10 (5 000 IU); DL-cholecalciferol, 20 (2 $000 \mathrm{IU})$; DL-adlpha-tocopherol acetate, 50 (25 IU); menadione, 3.0; thiamin hydrochloride, 7.5; riboflavin, 10; pyridoxin hydrochloride, 7.5; cyanocobalamine, 0.025; nicotinic acid, 100; ascorbic acid, 250; folic acid, 2.5; calcium pantothenate, 25; choline chloride, 1000 ; inositol, 500; biotin, 1.2; d mineral mix (mg/kg diet): calcium biphosphate $2 \mathrm{H}_{2} \mathrm{O}, 5000$; calcium carbonate, 2 150; sodium chloride, 400; potassium chloride, 900; magnesium hydroxide, 1240 ; zinc sulfate $\bullet 7 \mathrm{H}_{2} \mathrm{O}, 40$; manganese sulfate $\bullet \mathrm{H}_{2} \mathrm{O}, 30$; cuprous sulfate $\bullet 5 \mathrm{H}_{2} \mathrm{O}, 30$; cobalt sulfate, 0.2 ; potassium iodide, 0.4 ; ferric citrate $\bullet 7 \mathrm{H}_{2} \mathrm{O} 200$; sodium fluoride, 10 .

the known mean values of digestibility and heat of combustion of nutrients (Kim and Kaushik, 1992). Chromic oxide was added to a portion of each diet at a level of $1 \%$ as an inert marker for digestibility measurement.

\section{Digestibility trial}

Two trials were conducted to study the effect of temperature on digestibility using the same groups of fish in each trial. The 2 trials were performed with an opposite sequence of temperature.

During the first trial, 60 rainbow trout (Oncorhynchus mykiss) were randomly allotted to conical bottomed tanks (vol: $60 \mathrm{~L}$ ) supplied with recirculated water maintained at $8^{\circ} \mathrm{C}$ (flow rate: $4 \mathrm{~L} / \mathrm{min}$ ). Duplicate groups of 10 trout (mean body weight: $169 \mathrm{~g}$ ) were fed twice a day (daily ration: $1.3 \%$ of body weight) 1 of the experimen- tal diets. After a 5-day acclimation period, the faeces were continuously collected for a period of $9 \mathrm{~d}$ through rotative grids according to the procedure described by Choubert et al (1982a). Faeces from each tank were recovered and frozen twice a day. Subsequently, the water temperature was progressively increased up to $18^{\circ} \mathrm{C}$. During this transition period, which lasted $5 \mathrm{~d}$, the trout were fed the same commercial diet as they were fed before the first trial. The trout (mean body weight: $185 \mathrm{~g}$ ) were then acclimated to the new temperature and experimental diets for $8 \mathrm{~d}$. They were fed twice a day a daily ration of $1.6 \%$ of body weight. Faeces were collected for $9 \mathrm{~d}$.

During a second trial, dietary treatments were tested in triplicate with 17 fish per tank. Daily rations were the same as in the former trial. Digestibility was first measured at $18^{\circ} \mathrm{C}$. Trout (mean body weight: $95 \mathrm{~g}$ ) were acclimated to the respective diets for $6 \mathrm{~d}$ before the beginning of faeces collection. Faeces were collected for $9 \mathrm{~d}$. 
Water temperature was then decreased slowly (7d). Acclimation period to the new temperature $\left(8^{\circ} \mathrm{C}\right.$ ) lasted $13 \mathrm{~d}$. Faeces of trout (mean body weight: $125 \mathrm{~g}$ ) acclimated to the experimental diets for $7 \mathrm{~d}$ were then collected for $9 \mathrm{~d}$.

At the end of each trial, pooled, freeze-dried faecal samples were ground before analyses. Apparent digestibility coefficients (ADC) of nutrients and energy were calculated according to Maynard and Loosli (1969).

\section{Feeding trial}

The feeding trials were performed in 2 INRA experimental fish farms which differed in water temperature. The fish farm of Lees-Athas (Pyrénées-Atlantiques) is supplied with mountain spring water at a nearly constant temperature of $8 \pm 1{ }^{\circ} \mathrm{C}$. Three hundred rainbow trout (mean initial body weight: $56 \mathrm{~g}$ ) were randomly and equally allotted to 6 separate fibre-glass tanks (water volume $400 \mathrm{~L}$; flow rate: $20 \mathrm{~L} / \mathrm{min}$ ).

The fish farm of Donzacq (Landes) is supplied with water at a constant temperature of $18 \pm 1^{\circ} \mathrm{C}$ drawn from natural springs. Six hundred rainbow trout (mean initial body weight: $53 \mathrm{~g}$ ) were randomly and equally allotted to 6 individual sand bottomed compartments (water volume: $800 \mathrm{~L}$; flow rate: $240 \mathrm{~L} / \mathrm{min}$ ). Initial density of fish was maintained to be the same in the 2 feeding trials.

Both trials, which lasted 12 weeks, were carried out in winter (January to March), under natural photoperiod. Duplicate groups of fish, from the same strain in both trials, were fed by hand twice a day 1 of the experimental diets to near satiation (visual observation of first feed refusal). They were group-weighed and counted every 3 weeks, and feed intakes were recorded. Specific growth rate was calculated as:

$$
S G R=((\text { In BWt end }- \text { In BWt start }) / 83) \times 100
$$

Body composition analyses were performed on an initial sample of 10 fish and on groups of 5 fish which were withdrawn from each tank at the end of the experiment and killed after anaesthesia (ethylglycolmonophenylether $1 / 2500$ ). Whole bodies were frozen, freeze-dried, ground and pooled for each tank before analyses. Data allowed the calculation of retention efficiencies for protein and energy, which are equal to the ratio (nutrient or energy gained)/ (intake of digestible nutrient or digestible energy).

Estimations of non-faecal energy losses (through gill and urine excretions), metabolizable energy and total energy expenditure (fasting metabolic rate + heat increment of feeding + energy expended for activity) were made from the protein and energy retention according to Cho and Kaushik (1985). These parameters were expressed as percentage of digestible energy intake.

The amounts of digestible protein (DP) and digestible energy (DE) required for the production of $1 \mathrm{~kg}$ rainbow trout were also calculated as follows: (DP or DE intake (g) per fish during the period/(FBW - IBW)) $\times 1000$, where FBW and IBW represent the final and initial mean body weights, respectively.

\section{Chemical analyses}

The proximate compositions of the experimental diets (table I) and the chemical composition of the faeces and fish were determined using the following procedures: DM by drying in an oven at $110^{\circ} \mathrm{C}$ for $24 \mathrm{~h}$, ash by combustion at $550^{\circ} \mathrm{C}$ in a muffle furnace for $24 \mathrm{~h}$, crude protein (as $\mathrm{g} \mathrm{Nx}$ $6.25)$ by the Kjeldahl method after an acid digestion, lipid according to Folch et al (1957), starch using amylase and glucose oxidase (Thivend et al, 1972), gross energy with an adiabatic bomb calorimeter (IKA). Chromic oxide was measured after perchloric acid digestion (Bolin et al, 1952).

\section{Nitrogen excretion measurement}

Ammonia-nitrogen $\left(\mathrm{NH}_{4}{ }^{-} \mathrm{N}\right)$ excretion was measured first at $18^{\circ} \mathrm{C}$. Trout (mean body weight: $70 \mathrm{~g}$ ) were randomly allotted to 6 tanks (vol: $50 \mathrm{~L}$ ) supplied with thermoregulated recirculating water (flow rate: $1.7 \mathrm{~L} / \mathrm{min}$ ). Duplicate groups of 12 trout were fed twice a day (daily ration: $1.2 \%$ of body weight) one of the experimental diets for 3 weeks. Concentration of $\mathrm{NH}_{4}{ }^{+}-\mathrm{N}$ was measured in the water sampled from each tank and from a standard solution every hour during three $24 \mathrm{~h}$ cycles.

Water temperature was then decreased progressively $\left(1.5^{\circ} \mathrm{C} / \mathrm{d}\right)$ to $8^{\circ} \mathrm{C}$. Trout were acclimated to the new temperature for $8 \mathrm{~d}$. They continued to be fed the experimental diets twice a day (daily 
ration: $0.8 \%$ of body weight). Concentration of $\mathrm{NH}_{4}{ }^{+}-\mathrm{N}$ in water was measured as at $18^{\circ} \mathrm{C}$ during two 24-h cycles.

Concentrations of $\mathrm{NH}_{4}{ }^{+}-\mathrm{N}$ were measured using an autoanalyser (Alpkem) according to Le Corre and Treguer (1976).

Total nitrogen excretion was estimated to be $\mathrm{NH}_{4}{ }^{+-} \mathrm{N} / 0.85$ (Kaushik, 1980).

\section{Time-course study of plasma glucose}

Ninety rainbow trout were randomly allotted to 6 tanks at $8^{\circ} \mathrm{C}$ and 153 trout to 9 tanks at $18^{\circ} \mathrm{C}$. Fish (mean body weight: $120 \mathrm{~g}$ ) were acclimated to the same tanks as those used for the digestibility trial for 3 weeks before blood sampling. During this period, they were fed twice a day the experimental diets at a ration level of 1.6 and $1.8 \% \mathrm{BW}$ per day at 8 and $18^{\circ} \mathrm{C}$ respectively. They were then left unfed for $48 \mathrm{~h}$. Blood samples were collected first on 5 fasted trout under anaesthesia (ethylglycolmonophenylether: $1 / 4000$ ) for each dietary treatment ( 0 -sampling time). These trout were then discarded while the others were fed a meal of 1 of the experimental diets at the appropriate feeding level. At each selected time interval $(2,4,6,8,12,16,24$ and $30 \mathrm{~h}$ after feeding), 5-8 fed trout per dietary treatment were randomly removed from the tanks and anaesthetized. Blood was sampled from the caudal vein. A mixture of potassium oxalate $4 \%$ and sodium fluoride $4 \%$ was used to prevent coagulation and glycolysis. Each trout was sampled once or twice during the experiment. After the first blood sampling, fish were tagged by cutting the adipose fin. The second blood sampling on a same fish occurred at least $12 \mathrm{~h}$ after the first one. Blood was immediately centrifuged and plasma kept at $4^{\circ} \mathrm{C}$. Plasma glucose analyses were carried out within $4 \mathrm{~h}$ following sampling using a glucose analyser (Beckman II, USA).

\section{Statistical analyses}

The influence of dietary treatment on apparent digestibility coefficients and on nitrogen excretion was assessed by repeated measure of analysis of variance (Winer, 1971). This test also provided results on the influence of water temperature (repeated measures) and interac- tion between the 2 treatments. When the influence of the dietary treatment or the interaction was significant, the multiple comparison test of Bonferroni was performed. This test is appropriate when means are dependent unlike the Newman-Keuls' test which is more often used in current statistical analyses (Maxwell, 1980).

Two-way analyses of variance were performed to test the influence of dietary treatment, water temperature and their interaction on plasma glucose for each sampling-time. When a significant effect of the dietary treatment or of the interaction was found, means were compared using the multiple range test of Newman-Keuls.

Because experimental conditions were different between 8 and $18^{\circ} \mathrm{C}$ feeding trials, one-way analyses of variance were performed at each temperature to assess the influence of dietary treatment on growth performance and body composition. The multiple range test of NewmanKeuls was used to compare means when the effect of the dietary treatment was significant.

Statistical analyses were performed at a significance level of $5 \%$ using the SAS package (1987).

\section{RESULTS}

The results of the 2 digestibility trials were pooled, since they were not significantly different $(P>0.05)$. Hence, the data of digestibility are presented as the means of 5 values for each diet (table II). ADC of dietary components and energy were significantly lower in trout held at $8^{\circ} \mathrm{C}$ than in those held at $18^{\circ} \mathrm{C}$. The decrease in digestibility was small for protein (on average: $3.3 \%$ ) but more pronounced for lipid (on average: $8.6 \%$ ) and starch (on average: $17.3 \%$ ). At both temperatures, the ADC of starch was the lowest for trout fed the diet containing the highest level of crude starch (diet $L C$ ). ADC values of starch were similar for trout fed diets containing mainly gelatinized starch (diets $\mathrm{HC}$ and $\mathrm{MC}$ ) irrespective of the dietary level of crude starch. No significant effect of dietary treatment on ADC of protein and lipid was found $(P>0.05$ for each trial). The digestibility of energy was 
Table II. Effects of treatments (diet: HC, MC, LC; temperature: 8 or $18^{\circ} \mathrm{C}$ ) on apparent digestibility coefficients (ADC) of nutrients and energy, and digestible carbohydrate digestible lipid ratio (DC/DL) of diet for each treatment.

\begin{tabular}{|c|c|c|c|c|c|c|}
\hline \multirow[t]{3}{*}{ Diet } & \multicolumn{6}{|c|}{ Temperature } \\
\hline & \multicolumn{3}{|c|}{$8^{\circ} \mathrm{C}$} & \multicolumn{3}{|c|}{$18^{\circ} \mathrm{C}$} \\
\hline & $H C$ & $M C$ & $\angle C$ & $H C$ & $M C$ & $L C$ \\
\hline \multicolumn{7}{|l|}{$\mathrm{ADC}^{*}$} \\
\hline Protein & $85.3^{d}$ & $88.7 \mathrm{~cd}$ & $87.2^{\mathrm{cd}}$ & $88.7 a b c$ & $90.0^{a}$ & $89.3 \mathrm{ab}$ \\
\hline Lipid & $85.4 \mathrm{~b}$ & $88.1^{b}$ & $86.9^{b}$ & $94.0^{a}$ & $95.0^{a}$ & $93.9^{a}$ \\
\hline Starch & $69.5^{b}$ & $63.1^{b}$ & $41.2^{d}$ & $86.6^{a}$ & $84.6^{a}$ & $54.6^{c}$ \\
\hline Energy & $74.4^{c}$ & $76.1^{\circ}$ & $71.3^{\mathrm{c}}$ & $83.6^{a b}$ & $86.2^{a}$ & $80.6^{b}$ \\
\hline $\mathrm{DC} / \mathrm{DL}$ & 3.5 & 1.8 & 0.8 & 4.3 & 2.2 & 0.9 \\
\hline
\end{tabular}

\footnotetext{
* Data were arcsine transformed for normality before statistical analysis. Values in the same row with different superscript letters are significantly different $(P<0.05)$.
}

the highest for trout fed the diet containing a mixture of both starch and lipid (diet MC) but the difference was significant $(P<0.05)$ only at $18^{\circ} \mathrm{C}$. Consequently, digestible energy supplied by the experimental diets was not the same at both temperatures. Hence, experimental diets were not actually isoenergetic. However, 3 distinct digestible carbohydrate/digestible lipid ratios were obtained for both trials (table II).

Specific growth rates (SGR) were not influenced $(P>0.05)$ by the carbohydrate/lipid ratio of the diet for fish held at 8 or $18^{\circ} \mathrm{C}$. However, at $18^{\circ} \mathrm{C}$, final body weight tended to be higher $(P<0.10)$ in trout fed the diet with high lipid level (table III). Feed intake, feed gain ratio, and protein retention were not significantly influenced by dietary treatment at either temperature (table III). In contrast, at $18^{\circ} \mathrm{C}$, the amounts of digestible protein and digestible energy required for the production of $1 \mathrm{~kg}$ of trout were slightly but significantly lower for fish fed diets with high lipid content. At $8^{\circ} \mathrm{C}$, the dietary treatment did not influence $(P>0.05)$ these parameters (table III). Whole body protein content were not affected $(P>0.05)$ by dietary treatment at both temperatures (table III). At $8^{\circ} \mathrm{C}$, whole body lipid content, and thus, whole body energy contents, were similar $(P>0.05)$ in fish fed the 3 experimental diets. In contrast, at $18^{\circ} \mathrm{C}$, whole body lipid and energy content were higher in fish fed the diet with high lipid content (diet LC) (table III). This may be explained by significantly lower energy expenditure and thus, higher energy retention efficiencies for trout fed diet $L C$ relative to those fed diets $M C$ and $H C$ when they were reared at $18^{\circ} \mathrm{C}$. These parameters were not affected $(P>0.05)$ by dietary treatment at $8^{\circ} \mathrm{C}$ (table IV). Estimated values for non-faecal energy losses and for metabolizable energy (ME) were not affected by dietary treatment at either temperature (table IV).

The postprandial pattern of $\mathrm{NH}_{4}{ }^{+}$excretion was similar for the 3 groups of trout at each temperature (fig 1). Excretion peaks were more pronounced in trout held at $18^{\circ} \mathrm{C}$ than in those held at $8^{\circ} \mathrm{C}$. At $18^{\circ} \mathrm{C}, 2$ peaks were observed: the first at $13 \mathrm{~h}$ and the second at $20 \mathrm{~h}$ (ie $4 \mathrm{~h}$ after the meals). At $8^{\circ} \mathrm{C}$, 
Table III. Effects of dietary treatment $(\mathrm{HC}, \mathrm{MC}, \mathrm{LC})$ on intakes, growth performance and body composition of trout (initial mean body weight: $50 \mathrm{~g}$ ) held at 8 or $18^{\circ} \mathrm{C}$ for $84 \mathrm{~d}$.

\begin{tabular}{|c|c|c|c|c|c|c|}
\hline \multirow[t]{3}{*}{ Diet } & \multicolumn{6}{|c|}{ Temperature } \\
\hline & \multirow[b]{2}{*}{$H C$} & \multirow{2}{*}{$\frac{8^{\circ} \mathrm{C}}{M C}$} & \multirow[b]{2}{*}{$L C$} & \multicolumn{3}{|c|}{$18^{\circ} \mathrm{C}$} \\
\hline & & & & $H C$ & $M C$ & $L C$ \\
\hline \multicolumn{7}{|l|}{ Intake (per kg-trout per d) } \\
\hline Dry matter $(\mathrm{g})$ & 9.4 & 9.2 & 8.9 & 13.2 & 13.1 & 12.5 \\
\hline \multicolumn{7}{|l|}{ Growth performance } \\
\hline Final body weight (g) & 120.4 & 126.5 & 123.3 & 159.6 & 166.2 & 174.5 \\
\hline Specific growth rate (\%) & 0.9 & 1.0 & 0.9 & 1.3 & 1.4 & 1.5 \\
\hline Feed gain ratio $(\%)$ & 1.1 & 1.0 & 1.0 & 1.1 & 1.1 & 1.1 \\
\hline Protein retention (\%) & 44.9 & 44.7 & 44.6 & 43.7 & 43.9 & 47.7 \\
\hline DP */kg weight gain $(\mathrm{g})$ & 392.7 & 377.9 & 374.9 & 424.8 a & $418.7^{a}$ & $375.1^{\circ}$ \\
\hline $\mathrm{DE}{ }^{\star \star} / \mathrm{kg}$ weight gain $(\mathrm{kJ})$ & 15.0 & 15.3 & 15.2 & 17.5 ab & $18.8^{a}$ & $16.9^{b}$ \\
\hline \multicolumn{7}{|l|}{ Body composition } \\
\hline Dry matter $\left(\% W^{* \star \star *}\right)$ & 25.6 & 25.8 & 25.5 & 29.2 & 29.7 & 33.0 \\
\hline Protein (\% WW) & 17.0 & 16.8 & 16.8 & 18.2 & 18.2 & 17.9 \\
\hline Fat $(\%$ WW $)$ & 6.3 & 7.0 & 6.2 & $7.3^{b}$ & $8.6^{b}$ & $12.3 \mathrm{a}$ \\
\hline Energy (MJ/kg WW) & 6.3 & 6.5 & 6.2 & $7.3^{b}$ & $7.5^{b}$ & $8.9^{a}$ \\
\hline
\end{tabular}

* Digestible protein intake; ** digestible energy intake; *** wet weight; data expressed as percentages were arcsine transformed for normality before statistical analysis. For each temperature, values in the same row with different superscript letters are significantly different $(P<0.05)$.

Table IV. Effects of dietary treatment $(\mathrm{HC}, \mathrm{MC}, \mathrm{LC})$ on energy balance (expressed as percentage of digestible energy intake) of rainbow trout held at 8 or $18^{\circ} \mathrm{C}$.

\begin{tabular}{|c|c|c|c|c|c|c|}
\hline \multirow[t]{3}{*}{ Diet } & \multicolumn{6}{|c|}{ Temperature } \\
\hline & \multirow{2}{*}{$H C$} & \multirow{2}{*}{$\begin{array}{l}8^{\circ} \mathrm{C} \\
M C\end{array}$} & \multirow[b]{2}{*}{$L C$} & \multirow[b]{2}{*}{$H C$} & \multirow{2}{*}{$\frac{18^{\circ} \mathrm{C}}{M C}$} & \\
\hline & & & & & & $L C$ \\
\hline Non-faecal energy losses & 6.0 & 5.5 & 5.7 & 5.5 & 5.0 & 4.6 \\
\hline Metabolizable energy & 94.0 & 94.5 & 94.7 & 94.5 & 95.1 & 95.4 \\
\hline Total energy expenditure & 46.8 & 45.5 & 47.6 & $45.0 \mathrm{a}$ & $47.9 \mathrm{a}$ & $32.4^{b}$ \\
\hline Energy retention & 47.2 & 49.0 & 46.7 & $49.5^{b}$ & $47.1^{b}$ & $63.0^{a}$ \\
\hline
\end{tabular}

Data were arcsine transformed for normality before statistical analysis. For each temperature, values in the same row with different superscript are significantly different $(P<0.05)$. 


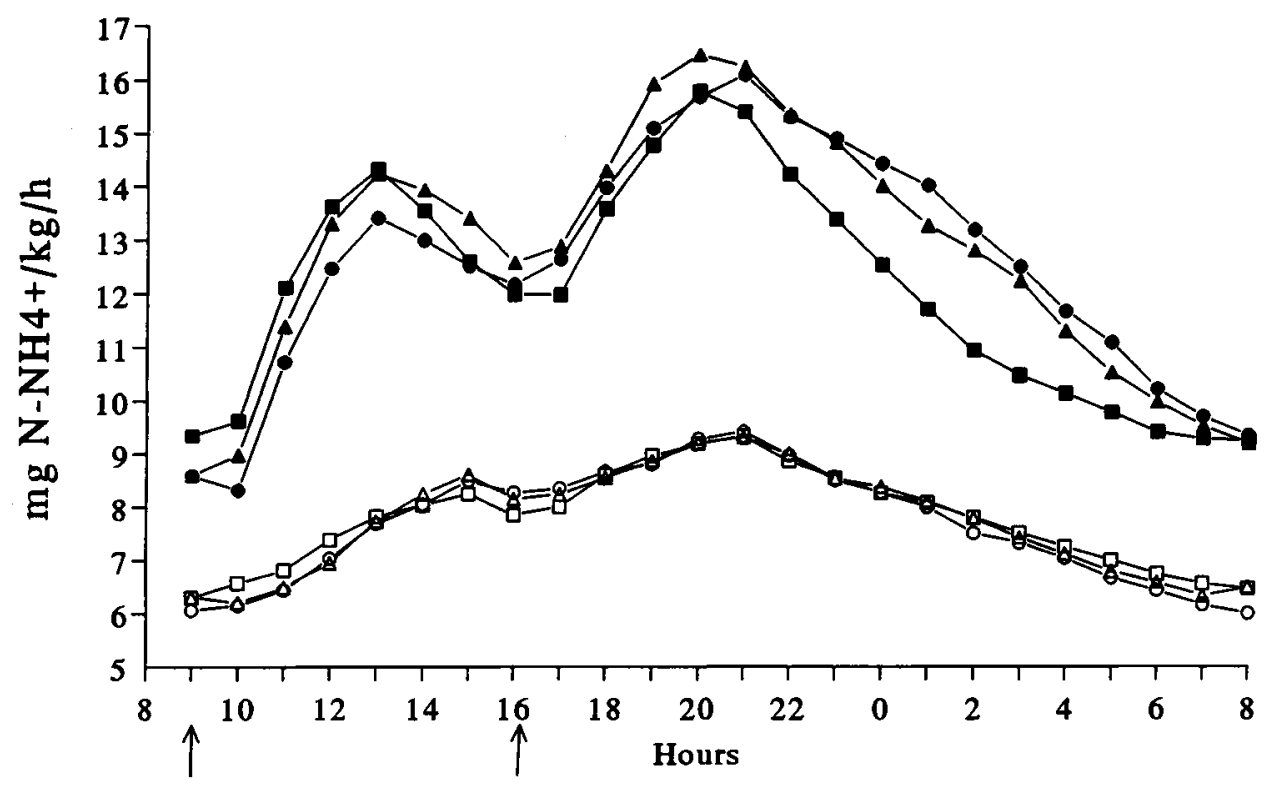

Fig 1. Effects of water temperature and dietary treatment (circles: HC; triangles: MC; squares: LC; closed marks: $18^{\circ} \mathrm{C}$ trial; open marks: $8^{\circ} \mathrm{C}$ trial) on time-course of ammonia-nitrogen excretion in rainbow trout. Arrows indicate the times of feeding.

the $\mathrm{NH}_{4}{ }^{+}$excretion increased slowly up to $15 \mathrm{~h}$, decreased slightly between 15 and $16 \mathrm{~h}$, and increased again up to $24 \mathrm{~h}$. The total nitrogen excretion during $24 \mathrm{~h}$ was not influenced $(P>0.05)$ by dietary treatment, but it was significantly higher at $18^{\circ} \mathrm{C}$ than at $8^{\circ} \mathrm{C}: 298$ and $185 \mathrm{mg} / \mathrm{kg} / \mathrm{d}$ respectively. However, expressed as percentage of digestible nitrogen intake, nitrogen excretion was not influenced $(P>0.05)$ by dietary treatment or water temperature, and was on average $52.6 \%$.

At each sampling time, the plasma glucose levels of trout that were sampled twice did not differ from those of trout sampled once only, showing that sampling the same fish twice at $12 \mathrm{~h}$ intervals did not affect the glycaemia levels.

Plasma glucose levels of trout increased within the first 2 to $4 \mathrm{~h}$ after the meal, irre- spective of temperature and diet (fig 2). The peak plasma glucose concentration was higher $(P<0.05)$ in trout fed diets with high digestible carbohydrate level. The daily pattern of glycaemia and the time of attainment of the peak of plasma glucose level were also influenced by water temperature. Peak of plasma glucose level was reached earlier at $18^{\circ} \mathrm{C}$ than at $8^{\circ} \mathrm{C}$ for trout fed diets $\mathrm{HC}$ and LC. Plasma glucose generally remained high $24 \mathrm{~h}$ after the meal in fish fed diets with high digestible carbohydrate levels, at both temperatures. However, plasma glucose returned nearly to the fasting level $30 \mathrm{~h}$ after the meal for trout reared at $18^{\circ} \mathrm{C}$ but not for trout reared at $8^{\circ} \mathrm{C}$, when they were fed diet HC. Water temperature also influenced plasma glucose levels of fish but this effect was dependent on the dietary treatment. For trout fed the diet with the high digestible carbohydrate level (diet HC), plasma 

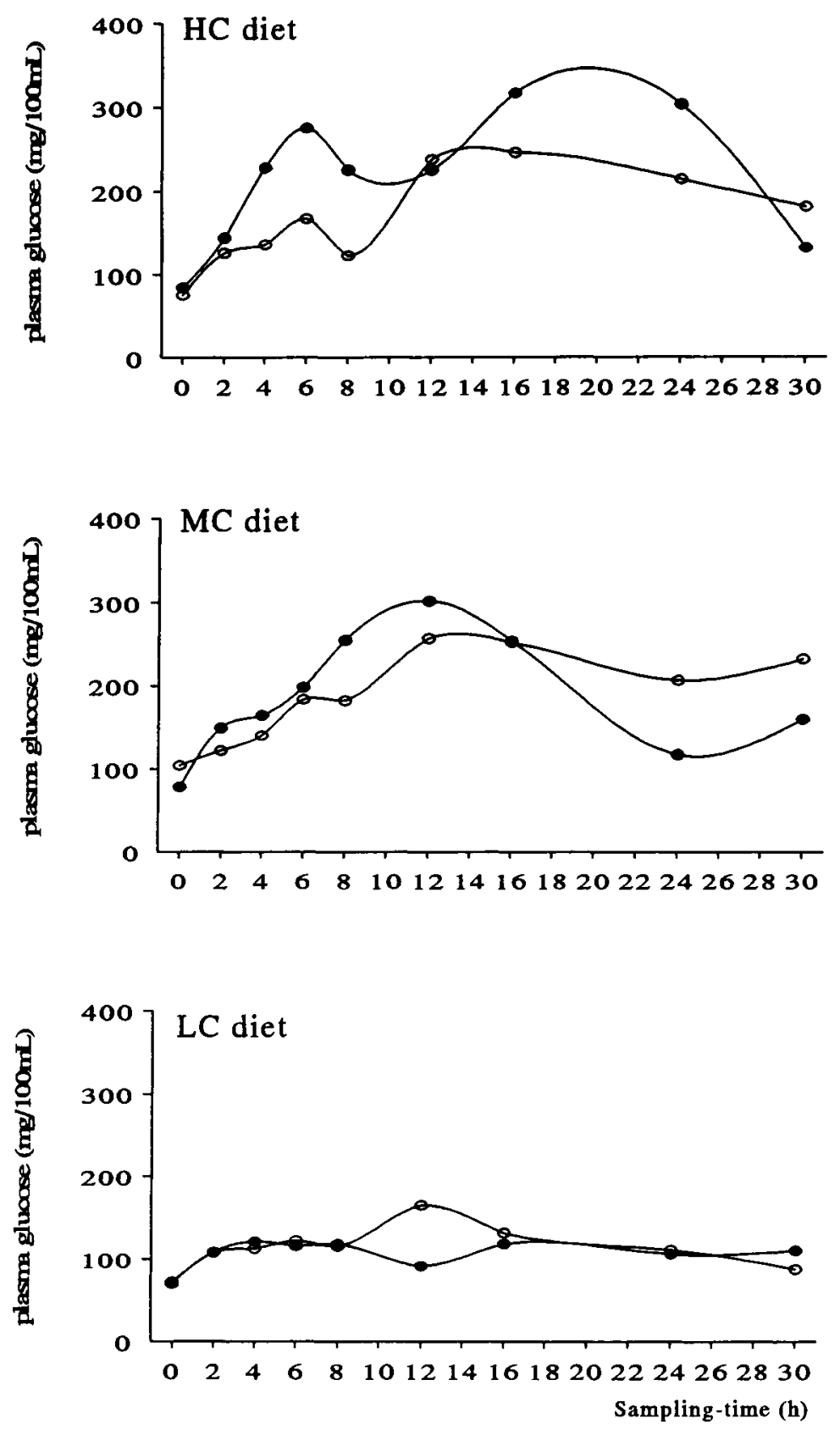

Fig 2. Time-course of plasma glucose in rainbow trout: effect of water temperature for each dietary treatment ( $\mathrm{HC}, \mathrm{MC}$ and $\mathrm{LC})$. Full lines represent the results of the $18^{\circ} \mathrm{C}$ trial and broken lines, the results of the $8^{\circ} \mathrm{C}$ trial. 
glucose was higher at $18^{\circ} \mathrm{C}$ than at $8^{\circ} \mathrm{C}$ between 4 and $24 \mathrm{~h}(P<0.05$ for times 4,6 and $8 \mathrm{~h}$ ). Thirty hours after the meal, plasma glucose tended to be lower, although not significantly, in fish held at $18^{\circ} \mathrm{C}$ than in those reared at $8^{\circ} \mathrm{C}$.

\section{DISCUSSION}

Nutrient and energy digestibility coefficients were higher in trout reared at high temperature than in those held at low temperature. Médale et al (1991) also observed an increase in ADC of crude and gelatinized starch with increased temperature in the same species. These results suggest that the activity of digestive amylase might be higher at high temperature in rainbow trout, as has been shown in roach, Rutilus rutilus (Hofer, 1979a). Choubert et a/ (1982b) and Oliva-Teles and Rodrigues (1993) also observed some improvement of the digestibilities of protein and energy by increasing water temperature in the same species. Gastric evacuation rate and total transit rate are increased by increasing temperature in several fish species (Fänge and Grove, 1979) including trout (Fauconneau et al, 1983). In another study, some digestive enzyme activities (proteases and amylase) are increased with increasing temperature in the roach (Hofer, 1979a, b). These 2 effects of water temperature are opposed: the first might decrease whereas the second might increase the digestibility of food at high temperature. This opposition might explain why an effect of water temperature on digestibility was not clearly proven in trout (Cho, 1987; Watanabe et al, 1989; Médale et al, 1991). Dietary treatment, water temperature range and/or genetic stock of trout might interact with the effect of water temperature on digestibility.

Our results showed that protein retention was not influenced by dietary carbohydrate/lipid ratio in trout, irrespective of water temperature. This is consistent with results of previous work where we observed that protein retention was not influenced by carbohydrate/lipid ratio in the diet of trout grown in seawater at $9^{\circ} \mathrm{C}$ (Brauge et al, 1994). Furthermore, in the present work, nitrogen excretion, expressed as percentage of digestible nitrogen intake, was not affected by dietary treatment. Digestible starch therefore seems to be as efficient as lipid in sparing protein. The protein-sparing effect of non-protein energy sources seems to be determined by the amount of digestible energy provided and not by the nature (lipid or carbohydrate) of the energy source in trout. Higgs et al (1992) also observed that isonitrogenous (crude protein: $39.5 \% \mathrm{DM}$ ) and isoenergetic (calculated digestible energy: $16.3 \mathrm{~kJ} / \mathrm{g} \mathrm{DM}$ ) diets differing by their carbohydrate/lipid ratio (HL, 0.3:17.6; ML, 13.8:13.1; LL, 24.4:7.4, in \%DM), with glucose as the carbohydrate source, led to the same protein retention efficiency. However, these authors concluded that trout do not efficiently utilize carbohydrate as an energy source because fish fed diets with a high carbohydrate level had lower food intake and weight gain, which differed from our results. These differences might be due to differences in water temperature, diets, especially carbohydrate source, or degree of satiation (feed intake: 1.0-1.3\% of body weight per day in Higgs et al, 1992, and $0.8 \%$ in our experiment).

At $18^{\circ} \mathrm{C}$, the amounts of digestible protein and energy required per unit weight gain were higher when high digestible carbohydrate level diets $\left(22-26 \%\right.$ at $18^{\circ} \mathrm{C}$ ) were provided to trout. This result is probably due to a higher energy expenditure when trout received the high carbohydrate diets. Beamish et al (1986) observed an increase in the heat increment of feeding with dietary carbohydrate levels in trout held at $15^{\circ} \mathrm{C}$ and fed isonitrogenous and isoenergetic diets. In mammals, an increase in dietary carbohydrate levels results in increasing 
heat increment of feeding, due to the transformation of dietary glucose into body lipids (Acheson et al, 1984).

Lipogenesis from carbohydrate is also effective in rainbow trout and increases with increasing carbohydrate/lipid ratio (Henderson and Sargent, 1981; Brauge et al, 1995). Hence, the higher energy expenditure observed in trout held at high temperature and fed the high digestible carbohydrate diet might be due to a higher lipogenesis. This phenomenon might also be due to an influence of high dietary carbohydrate levels on glucose transport and/or excretion as supposed by Beamish et al (1986). However, dietary carbohydrate/lipid ratio had no effect on the energy expenditure of trout held at the low temperature of $8^{\circ} \mathrm{C}$. Consequently, trout fed the diet with the high lipid level had higher body fat content than those fed the diet with the low lipid level at high temperature, but not at low temperature. Studies have shown that body lipid levels are related to dietary lipid level in fish (Adron et al, 1976; Reinitz et Hitzel, 1980; Watanabe, 1982). However, in these studies, an increase in dietary lipid level was associated with an increase in dietary energy levels, whereas, in the present work, the level of digestible energy intake was roughly the same in the 3 groups of fish. Hence, the nature (carbohydrate or lipid) of the non-protein energy source of the diet influences the body lipid composition of trout held at high temperature. However, this effect seems to interact with temperature since we did not observe any difference in body lipid levels of trout held at low temperature. More studies are thus needed to understand the interaction between dietary carbohydrate/lipid ratio and water temperature on energy metabolism of trout.

The ammonia excretion of trout had a typical course after feeding (Rychly and Marina, 1977; Kaushik, 1981). The pattern of nitrogen excretion depends on the species, the size and composition of the meal, and on the water temperature (Kaushik, 1980, 1981; Kaushik and OlivaTeles, 1985; Cui and Liu, 1990). The effect of water temperature on feed intake (Kaushik, 1981) and on transit rate (Fauconneau et al, 1983) may explain, in our experiment, why the effect of the second meal is more obvious at $18^{\circ} \mathrm{C}$ than at $8^{\circ} \mathrm{C}$. The elevated nitrogen excretion of trout reared at $18^{\circ} \mathrm{C}$, relative to those held at $8^{\circ} \mathrm{C}$, may result from the effect of water temperature on feed intake, since nitrogen excretion was not influenced by water temperature when expressed as percentage of digestible nitrogen intake. This result agrees with Kaushik (1981).

Plasma glucose concentrations were higher in trout fed diets with high digestible carbohydrate levels than in those fed the diet with low digestible carbohydrate level. Similar results have been observed previously in $60-100 \mathrm{~g}$ trout held in freshwater at 18 or $12^{\circ} \mathrm{C}$ (Bergot, 1979; Himick et al, 1991) and in $300 \mathrm{~g}$ trout held in seawater at $9^{\circ} \mathrm{C}$ (Brauge et al, 1994) with glucose, dextrin or digestible starch as carbohydrate source. Moreover, plasma glucose levels were higher at $18^{\circ} \mathrm{C}$ compared with those at $8^{\circ} \mathrm{C}$ during the $10 \mathrm{~h}$ after the meal when trout were fed diets with high digestible carbohydrate content. This result may be explained by a higher availability of carbohydrate at high temperatures than at low temperatures when fish were fed diets containing high digestible carbohydrate levels. Indeed, the amounts of digestible carbohydrate ingested by a $100 \mathrm{~g}$ fish per meal were higher at elevated temperatures which led to higher plasma glucose levels in trout reared at $18^{\circ} \mathrm{C}$ than in those reared at $8^{\circ} \mathrm{C}$. Finally, increases in the rates of carbohydrate digestion and absorption due to elevated temperatures may explain why the peak of plasma glucose was attained earlier in trout held at high temperature relative to those held at low temperature. Oxidative catabolism of glucose has also been shown 
to be higher in another teleost, Dicentrarchus labrax, held at a high temperature rather than at a low temperature (Garin, 1984). Such an effect of temperature in rainbow trout might explain the more rapid fall of plasma glucose at high temperature than at low temperature.

\section{CONCLUSION}

This study showed that digestible carbohydrates, supplied as gelatinized wheat starch, were as efficient as lipids in maintaining high protein retention in rainbow trout. By contrast, the source of non-protein energy influenced total energy expenditure and lipid deposition at high temperature, but not at low temperature. Temperature also influenced the digestibility of nutrients and energy and time-course of plasma glucose. Although plasma glucose levels were high for trout fed diets with high digestible carbohydrate content, the trout grew well irrespective of dietary treatment at both temperatures. Nitrogen excretion was elevated in trout reared at $18^{\circ} \mathrm{C}$ because of a higher feed intake relative to trout held at $8^{\circ} \mathrm{C}$. Further work is needed to understand the effect of the interaction between temperature and non-protein energy sources on energy and lipid metabolism of trout.

\section{ACKNOWLEDGMENTS}

This study was supported by a research grant from IFREMER (Institut Français pour la Recherche et l'Exploitation de la Mer) and the district of Aquitaine (France).

\section{REFERENCES}

Acheson KJ, Schutz Y, Bessard T, Ravussin E, Jéquier E, Flatt JP (1984) Nutritional influences on lipogenesis and thermogenesis after a carbohydrate meal. Am J Physiol 246, E62-E70
Adron JW, Blair A, Cowey CB, Shanks AM (1976) Effects of dietary energy level and dietary energy source on growth, feed conversion and body composition of turbot (Scophthalmus maximus). Aquaculture 7, 125132

Beamish FWH, Hilton JW, Niimi E, Slinger SJ (1986) Dietary carbohydrate and growth, body composition and heat increment in rainbow trout (Salmo gairdneri). Fish Physiol Biochem 1, 85-91

Bergot $F$ (1979) Effects of dietary carbohydrates and of their mode of distribution on glycaemia in rainbow trout (Salmo gairdneri Richardson). Comp Biochem Physiol 64A, 543-547

Bergot $F$, Brèque J (1983) Digestibility of starch by rainbow trout; effects of the physical state of starch and of the intake level. Aquaculture 34, 203-212

Bolin DW, King RP, Klosterman WW (1952) A simplified method for the determination of chromic oxide $\left(\mathrm{Cr}_{2} \mathrm{O}_{3}\right)$ when used as an inert substance. Science 16, 634-635

Brauge C, Médale F, Corraze G (1994) Effect of dietary carbohydrate levels on growth, body composition and glycaemia in rainbow trout, Oncorhynchus mykiss, reared in seawater. Aquaculture 123, 109120

Brauge C, Corraze G, Médale F (1995) Effects of dietary levels of carbohydrate and lipid on glucose oxidation and lipogenesis from glucose in rainbow trout, Oncorhynchus mykiss, reared in freshwater or in seawater. Comp Biochem Physiol (in press)

Cho CY (1987) Studies on nutritional energetics and protein utilization in rainbow trout (Salmo gairdneri Richardson). Thesis, Kyushu University, Fukuoka, Japan

Cho CY, Kaushik SJ (1985) Effects of protein intake on metabolizable and net energy values of fish diets. In: Nutrition and Feeding in Fish. Academic Press, London, UK, 95-117

Choubert G, De la Noüe J, Luquet P (1982a) Digestibility in fish: improved device for the automatic collection of feces. Aquaculture 29, 185-189

Choubert G, Fauconneau B, Luquet $P$ (1982b) Influence d'une élévation de la température de l'eau sur la digestibilité de la matière sèche, de l'azote et de l'énergie de l'aliment distribué à la truite Arc-en-ciel (Salmo gairdneri Rich). Reprod Nutr Develop 22, 941-949

Cui Y, Liu J (1990) Comparison of energy budget among six teleosts. I. Food consumption, faecal production and nitrogenous excretion. Comp Biochem Physiol 96A, 163-171

De Silva SS, Gunasekera RM, Shim KF (1991) Interactions of varying dietary protein and lipid levels in young red tilapia: evidence of protein sparing. Aquaculture 95, 305-318

Dixon DG, Hilton JW (1985) Effects of available dietary carbohydrate and water temperature on the chronic 
toxicity of waterborne copper to rainbow trout (Salmo gairdneri). Can J Fish Aquat Sci 42, 1007-1013

Fänge R, Grove D (1979) Digestion. In: Fish Physio/ogy. Vol VIII. Bioenergetics and Growth (WS Hoar, DJ Randall, JR Brett, ed) Academic Press, New York, USA, 161-260

Fauconneau $B$, Choubert $G$, Blanc $D$, Brèque J, Luquet $P(1983)$ Influence of environmental temperature on flow rate of foodstuffs through the gastrointestinal tract of rainbow trout. Aquaculture 34, 27-39

Folch J, Lees M, Sloane Stanley GH (1957) A simple method for the isolation and purification of total lipids from animal tissues. J Biol Chem 226, 497-509

Garin D (1984) Influence de la salinité sur I'utilisation oxydative du glucose et du glutamate par le loup (Dicentrarchus labrax). Ichtyophysiol Acta 8, 58-74

Henderson RJ, Sargent JR (1981) Lipid biosynthesis in rainbow trout, Salmo gairdneri, fed diets of differing lipid content. Comp Biochem Physiol 69C, 31-37

Higgs DA, Dosanjh BS, Uin LM, Himick BA, Eales JG (1992) Effects of dietary lipid and carbohydrate levels and chronic 3,5'3'-triiodo-L-thronine treatment on growth, appetite, food and protein utilization and body composition of immature rainbow trout, Oncorhynchus mykiss, at low temperature. Aquaculture 105, 175-190

Hilton JW, Plisetskaya EM, Leatherland JF (1987) Does oral 3,5,5'-triiodo-L-thyronine affect dietary glucose utilization and plasma insulin levels in rainbow trout (Salmo gairdneri)? Fish Physiol Biochem 4, 113-120

Himick BA, Higgs AH, Eales JG (1991) The acute effects of alteration in the dietary concentrations of carbohydrate, protein, and lipid on plasma T4, T3 and glucose levels in rainbow trout, Oncorhynchus mykiss. Gen Comp Endocrino/ 82, 451-458

Hofer R (1979a) The adaptation of digestive enzymes to temperature, season and diet in roach, Rutilus rutilus $\mathrm{L}$ and rudd, Scardinius erythrophthalmus L. 1. Amylase. J Fish Biol 14, 565-572

Hofer R (1979b) The adaptation of digestive enzymes to temperature, season and diet in roach, Rutilus rutilus $\mathrm{L}$ and rudd, Scardinius erythrophthalmus; Proteases. J Fish Biol 15, 373-379

Jeong KS, Takeuchi T, Watanabe T (1991) Improvement of nutritional quality of carbohydrate ingredients by extrusion process in diets of red sea bream. Nippon Suisan Gakkaishi 57, 1543-1549

Kaushik SJ (1980) Influence of nutritional status on the kinetics of daily nitrogen excretion in carp (Cyprinus carpio $L$ ) and rainbow trout (Salmo gairdneri $\mathrm{R}$ ) Reprod Nutr Devel 20, 1751-1765

Kaushik SJ (1981) influence of a rise in temperature on the nitrogen excretion of rainbow trout (Salmo gairdneri R). In: Aquaculture in Heated Effluents and Recirculation Systems. Vol I (K Tiews, ed), Bunderforschungsanstalt für Fischerei, Berlin, Germany, $77-82$
Kaushik SJ, Oliva-Teles A (1985) Effect of digestible energy on nitrogen and energy balance in rainbow trout. Aquaculture 50, 89-101

Kaushik SJ, Médale F, Fauconneau B, Blanc D (1989) Effect of digestible carbohydrates on protein/energy utilization and on glucose metabolism in rainbow trout (Salmo gairdneri R). Aquaculture 79, 63-74

Kim JD, Kaushik SJ (1992) Contribution of digestible energy from carbohydrates and estimation of protein/energy requirements for growth of rainbow trout (Oncorhynchus mykiss). Aquaculture 106, 161-169

Le Corre P, Treguer P (1976) Contribution à l'étude de la matière organique dissoute et des sels nutritifs dans l'eau de mer. Caractéristiques chimiques du Golfe de Gascogne et des upwellings côtiers de l'Afrique du Nord-Ouest. PhD, université de Bretagne Occidentale, Brest, France, $490 \mathrm{p}$

Lee DJ, Putnam GB (1973) The response of rainbow trout to varying protein/energy ratios in a test diet. J Nutr 103, 916-922

Maxwell SE (1980) Pairwise multiple comparisons in repeated measures designs. J Educ Stat 5, 269-287

Maynard LA, Loosli JK (1969) Animal Nutrition. 6th Ed, McGraw-Hill, New York, USA

Médale F, Aguirre P, Kaushik SJ (1991) Utilization of dietary carbohydrates by rainbow trout at two water temperatures. In: Energy Metabolism of Farm Animals, European Association for Animal Production Pub 58 (C Wenk, M Boessinger, ed), 391-395

Oliva-Teles A, Rodrigues AM (1993) The effect of high temperature and diet protein level on metabolic utilization of diets by rainbow trout. In: Fish Nutrition in Practice (SJ Kaushik, P Luquet, ed) INRA, Paris, France, 301-305

Pieper A, Pfeffer E (1980) Studies on the comparative efficiency of utilization of gross energy from some carbohydrates, proteins and fats by rainbow trout (Salmo gairdneri R). Aquaculture 20, 323-332

Reinitz G, Hitzel F (1980) Formulation of practical diets for rainbow trout based on desired performance and body composition. Aquaculture 19, 243-252

Reinitz GL, Orme LE, Lemm CA, Hitzel FN (1978) Influence of varying lipid concentrations with two protein concentrations in diets for rainbow trout (Salmo gairdneri). Trans Am Fish Soc 107, 751-754

Rychly J, Marina BA (1977) Nitrogen balance in trout. II. Nitrogen excretion and retention after feeding diets with varying protein and carbohydrate levels. Aquaculture 11, 173-178

SAS (1987) SAS/Stat Guide for Personal Computers. SAS Inst Inc, NC, USA

Singh RP, Nose T (1967) Digestibility of carbohydrates in young rainbow trout. Bull Freshw Fish Res $L a b$ $17,21-25$

Takeuchi T, Watanabe T, Ogino $C$ (1978) Optimum ratio of protein to lipid in diets in rainbow trout. Bull Jpn Soc Sci Fish 44, 683-688 
Takeuchi T, Jeong KS, Watanabe T (1990) Availability of extruded carbohydrate ingredients to rainbow trout (Oncorhynchus mykiss) and carp (Cyprinus carpio). Nippon Suisan Gakkaishi 56, 1839-1845

Thivend P, Mercier C, Guilbot A (1972) Determination of starch with glucoamylase. In: Methods in Carbohydrate Chemistry, Vol VI (RL. Whistler, JN Bemiller, ed), Academic Press, New York, London, 100-105
Watanabe T (1982) Lipid nutrition in fish. Comp Biochem Physiol 73B, 3-15

Watanabe T, Takeuchi T, Satoh S (1989) The digestible crude protein content of practical feed ingredients determined in freshwater fish. IIIrd Int Symp Feeding and Nutrition in Fish, Toba, Japan (Abst)

Winer BJ (1971) Statistical Principals in Experimental Design, 2nd Edition, McGraw-Hill Book Co, New York, USA 